\title{
FACTORS THAT CAN INFLUENCE IN ROMANIA THE PARENTS' DECISION REGARDING THE ANTI COVID-19 VACCINATION OF CHILDREN AND ADOLESCENTS AGED 12-15
}

\author{
Petru Sandu', Daniela Rajka², Ancuța Pintea ${ }^{2}$, Kristina Moldovan'2, \\ Sebastian Pintea ${ }^{3}$, Tudor L Pop ${ }^{4}$ \\ ${ }^{1}$ National Institute of Public Health - Cluj Regional Center for Public Health \\ ${ }^{2}$ School and student medical offices, Cluj-Napoca \\ ${ }^{3}$ Department of Psychology, Babes-Bolyai University, Cluj-Napoca \\ ${ }^{4}$ Pediatrics 2 Department, “Mother and child” Department, „Iuliu Haţieganu” University of Medicine and \\ Pharmacy Cluj-Napoca, \\ Pediatrics 2 Clinic, Emergency Clinical Hospital for Children Cluj-Napoca
}

\begin{abstract}
INTRODUCTION: Mass population vaccination remains one of the safest methods in the fight against the SARS-CoV-2 virus pandemic. Although children were less affected by the disease at the beginning of the epidemic, recent data show an increase in the number of infected children and of the severe forms they develop. Approval of the use of an anti-COVID-19 vaccine in minors aged 12 or more was an important step in limiting the infection.

OBJECTIVES: The main objective of our study is to evaluate the intention of Romanian parents to vaccinate their children aged between 12 and 15 against the SARS-CoV-2 virus. The information, attitudes, opinions and factors that may influence parents' decision to accept or not the vaccination of their children against SARS-CoV-2 virus were also studied.

METHODS: A questionnaire with predetermined / free answers was distributed online, between 20.05-09.06.2021, through school doctors from all development regions of Romania, to parents of children from grades $\mathrm{V}^{\text {th }}$ to $\mathrm{VIII}{ }^{\text {th }}$, aged 12-15. The platform
\end{abstract}

used to administer the online questionnaire was Google Forms. The results were analyzed, and statistical correlations were established between the vaccination intention and demographic, socio-economic factors, vaccination status and family risk factors.

RESULTS: Of the 3524 parents surveyed, $32.57 \%$ expressed their intention to vaccinate their children against COVID-19. The reasons why parents intend to vaccinate their children are represented in $92.5 \%$ of cases by the desire to protect their children against infection. In addition, the protection of a person at risk in the family is considered a good reason for vaccinating their children by $23.34 \%$ of parents, while $38 \%$ want to vaccinate their children also out of the desire to be able to travel without restrictions.

The reasons why parents do not want to vaccinate their children against COVID-19 are: the fact that they do not consider the vaccination necessary for children $(49.45 \%)$, the fear of side effects $(46.75 \%)$ or because they do not trust vaccines $(21.63 \%)$.

\footnotetext{
* Corresponding author: Sandu Petru, National Institute of Public Health - Cluj Regional Center for Public, e-mail: petru.sandu@insp.gov.ro Article received: 22.06.2021, accepted: 7.07.2021, published: 10.07.2021 Citing: Sandu P, Rajka D, Pintea A, Moldovan K, Pintea S, Pop LT. Factors that can influence in Romania the parents' decision regarding the anti COVID-19 vaccination of children and adolescents aged 12-15. The Journal of School and University Medicine. 2021;VIII(2):19-29
} 
The intention to vaccinate is significantly correlated with the older age of the parents, the high level of education, and the domicile in county seat cities. An important statistical correlation was found between the vaccinated status of the parents and the intention to vaccinate their children, as well as between this intention and the existence of a severe form of COVID-19 disease in the family and the presence of people at high risk of developing a severe form of illness in the family.

CONCLUSIONS: Studies on the intention to vaccinate children aged 12-15 against COVID-19 are not very numerous worldwide, but our study identifies the same hesitations and reasons for parents' acceptance / non-acceptance of vaccinating their children. Communicating the correct information is very important to increase the confidence and acceptability of the vaccine.

\section{KEY WORDS: anti-COVID-19 vaccine, chil- dren aged 12-15, vaccination intention}

\section{INTRODUCTION}

The fight against the SARS-CoV-2 infection remains as important after a year and a half since the first cases emerged. As vaccination of the population is one of the safest and most effective methods of eradicating the disease, the question we are asking is: what role can the vaccination of children and adolescents play in limiting the pandemic? [1]

Studies to date suggest that adolescents aged 10-14 years are less susceptible to SARS-CoV-2 virus infection than adults, while those aged 15-18 years are similarly susceptible as adults [2].

At the same time, studies highlight the role of infected children and adolescents in transmitting the disease to other children, but also to adults [3-6].

In order to reduce the transmission of SARSCoV-2 virus infection vaccination of children and adolescents is also required [1]. Without vaccination, children will be a reservoir that would reduce the chances of controlling and eradicating the pandemic [7].

Although the risk of children developing a severe form of the disease is low, some children have developed complications, including multisystemic inflammatory syndrome, while others have had symptoms for a long time, similar to adults [8 - 11].
In the United States, about 4 million children have been diagnosed with COVID-19 since the beginning of the pandemic, and about 300 have died [12].

Although children were less affected at the beginning of the epidemic, recent data show an increase in the number of infected children and the severe forms they develop, suggesting that the virus has changed. The rate of hospitalization in adolescents increased between March and April 2021, and almost 1/3 of recently hospitalized children were admitted to an ICU (Intensive Care Unit) ward, according to the Center for Disease Control and Prevention (CDC) [13].

The approval to use anti-COVID-19 vaccines, initially in the 16-18 age group, then in the 12-15 age group, was an important step in the fight against the pandemic, because a safe and effective vaccine for adolescents has major direct (individual) and indirect (population) benefits [14].

Vaccination of children and adolescents against the SARS-CoV-2 virus, in addition to reducing their risk of developing a severe form of the disease, reduces the transmission of the disease in the family, reduces stress, promotes the normalization of the economy and the safe opening of schools [15].

For minors, it is the parents who have the legal right to decide on vaccination. Therefore, it is important to understand their concerns about vaccination, to know the barriers felt, and to provide accurate information to decision-makers and health professionals on issues that can positively influence the attitude toward vaccination and the decision to vaccinate children and adolescents aged 12-15 from Romania.

Positive public opinion and confidence in the vaccine are essential, and parents' hesitations about the safety of a new vaccine are normal $[16,17]$.

Studies conducted in this regard have tried to identify the obstacles felt by parents, the most important being related to the safety and efficacy of the vaccine in children and adolescents [15,18-23].

\section{OBJECTIVES}

The main objective of our study is to assess the parents' intention to vaccinate their children against the Sars-Cov-2 virus, given that there is a vaccine approved by the European Medicines Agency (EMA) for the 12-15 age group. 
The information, attitudes, opinions and factors that may influence parents' decision to accept or not to vaccinate their children against the SARS-CoV-2 virus were also studied.

\section{METHODS}

A questionnaire with pre-set / free answers was distributed online, between May $20^{\text {th }}$ and June $9^{\text {th }}$ 2021, through school doctors from all development regions of Romania, to parents who have children in grades $\mathrm{V}^{\text {th }}$ to VIII ${ }^{\text {th }}$, aged 12-15.

The platform used to administer the online questionnaire was Google Forms

The questionnaire included questions on demographic and social factors, the vaccination status of children and parents, reasons that may influence the vaccination decision (e.g. people with chronic illnesses in the family and / or who have gone through a medium / severe form of COVID-19 disease).

The results were analyzed, statistical correlations were established between the vaccination intention and demographic, socio-economic factors, vaccination status and family risk factors.

\section{RESULTS}

Of the 4737 filled questionnaires we received, 3524 were taken into account, i.e. those sent by parents of children aged 12-15 years. Of these, 2949 stated that they have only one child in this age interval, while 575 have 2 or more children aged 12-15.

\section{Socio-demographic factors}

Development region: The questionnaire was answered by parents from all 8 development regions of Romania (Table no. 1), from rural areas (43.3\%), small towns (31.12\%) and county seat cities $(25.56 \%)$ . The most answers were received from the South Muntenia Region and the least from the Eastern regions (North-East and South-East), more likely to be related to the way the questionnaire link was distributed and less related to the availability to participate in the study.

Table number 1. Parents' region of domicile

\begin{tabular}{lc}
\hline București/ Ilfov & $\mathbf{2 2 0}$ \\
\hline Center Region: Alba, Brașov, Covasna, Harghita, Mureș and Sibiu & $\mathbf{5 3 6}$ \\
\hline North-East Region: Bacău, Botoșani, Iași, Neamț, Suceava and Vaslui & $\mathbf{2 5}$ \\
\hline North-West Region: Bihor, Bistrița-Năsăud, Cluj, Maramureș, Satu-Mare and Sălaj & $\mathbf{2 0 0}$ \\
\hline South - Muntenia Region: Argeș, Călărași, Dâmbovița, Giurgiu, Ialomița, Prahova, Teleorman & $\mathbf{2 1 6 2}$ \\
\hline South-East Region: Brăila, Buzău, Constanța, Galați, Tulcea and Vrancea & $\mathbf{2 6}$ \\
\hline South-West-Oltenia Region: Dolj, Gorj, Mehedinți, Olt and Vâlcea & $\mathbf{2 1 2}$ \\
\hline West Region: Arad, Caraș-Severin, Hunedoara and Timiș & $\mathbf{1 4 3}$ \\
\hline TOTAL & $\mathbf{3 5 2 4}$ \\
\hline
\end{tabular}

The average age of the parents participating in Level of education: the vast majority of rethe study was 40.36 years. spondents have graduated high school, post-secondary school and higher education (Table no. 2).

Table number 2. Parents' domicile and level of education

\begin{tabular}{ccccccc}
\hline Domicile & \multicolumn{6}{c}{ Level of education } \\
\hline & $\begin{array}{c}\text { Without } \\
\text { studies }\end{array}$ & $\begin{array}{c}\text { Gymna- } \\
\text { sium }\end{array}$ & $\begin{array}{c}\text { High } \\
\text { school }\end{array}$ & $\begin{array}{c}\text { Post-secondary } \\
\text { school }\end{array}$ & $\begin{array}{c}\text { Higher } \\
\text { education }\end{array}$ & TOTAL \\
\hline Commune / village & 4 & 298 & 632 & 220 & 372 & $\mathbf{1 5 2 6 ( 4 3 , 3 \% )}$ \\
\hline City & 2 & 76 & 399 & 183 & 437 & $\mathbf{1 0 9 7 ( 3 1 , 1 2 \% )}$ \\
\hline County seat city & 1 & 23 & 131 & 101 & 645 & $\mathbf{9 0 1 ( 2 5 , 5 6 \% )}$ \\
\hline TOTAL & $\mathbf{7}$ & $\mathbf{3 9 7}$ & $\mathbf{1 1 6 2}$ & $\mathbf{5 0 4}$ & $\mathbf{1 4 5 4}$ & $\mathbf{3 5 2 4}$ \\
\hline
\end{tabular}


The average age of the children included in the study was 13.42 years, of which 1165 were 12 years old, 942 were 13 years old, 839 were 14 years old, and 1003 were 15 years old.

\section{Vaccination status}

Parents' anti-COVID-19 vaccine status

$46,87 \%$ of the parents who responded to our questionnaire are vaccinated against SARS-CoV-2 with one of the EMA approved vaccines. (Table no. 3).

Table number 3. Anti COVID-19 vaccination in parents included in the study

\begin{tabular}{cccccc}
\hline $\begin{array}{c}\text { Have you personally been vaccinated } \\
\text { against COVID-19? }\end{array}$ & Astra-Zeneca & $\begin{array}{c}\text { Johnson \& } \\
\text { Johnson }\end{array}$ & Moderna & Pfizer-Biontech & TOTAL \\
\hline YES & 239 & 61 & 68 & 1284 & $\mathbf{1 6 5 2}$ \\
\hline NO & & & & $\mathbf{1 8 7 2}$ \\
\hline TOTAL & & & & 3524 \\
\hline
\end{tabular}

Vaccination of children according to the national immunization programme

Among children aged 12-15 of the parents participating in the study, $66.68 \%(\mathrm{~N}=2350)$ are fully vaccinated according to the national immunization programme, while $27.86 \%(\mathrm{~N}=982)$ of the children were NOT vaccinated with any vaccine from this programme and $5.44 \%(\mathrm{~N}=192)$ received an incomplete vaccination schedule.

\section{Intention to vaccinate children}

The vast majority (77.78\%) of the parents included in the study stated that they had heard that some vaccines would be authorized for children aged $12-15$, and 1148 (32.57\%) of the parents who participated in the study had stated their intention to vaccinate their child/ children when a vaccine would be available.
Knowledge, attitudes and factors that influence the anti SARS-CoV-2 vaccination

Regarding their own anti SARS-CoV-2 vaccination, the most frequently reported reasons why the $1872(53.12 \%)$ parents in the study were not vaccinated are: fear of side effects $(42.89 \%)$, distrust of vaccines $(28.73 \%)$, were already infected $(14.42 \%)$, failure to make an appointment $(12.23 \%)$, medical problems or pregnancy / breastfeeding (1.98\%).

Regarding the motivation to vaccinate themselves or their children, more than a third of the respondents $(37.34 \%, \mathrm{~N}=1316)$ stated that they have people in the family with risk factors for the development of a severe form of the disease (elderly, people with chronic diseases), and $33.71 \%, \mathrm{~N}=1188$, of the parents declare that they were infected with the SARS-CoV-2 virus.

$8.68 \%$ of the respondents had severe forms of illness in the family (Table no. 4).

Table number 4. Severe forms of COVID-19 in the family

\begin{tabular}{lc}
\hline Have you or anyone in your family had a severe form of COVID-19? & $\mathbf{8 0}$ \\
\hline Someone in the family died & $\mathbf{2 1}$ \\
\hline Someone in the family has been in the ICU & $\mathbf{2 0 5}$ \\
\hline Someone in the family was hospitalized & 3218 \\
\hline Nobody in the family had a severe form of illness & 3524 \\
\hline TOTAL &
\end{tabular}

Reasons for the decision to vaccinate / not vaccinate children against SARS-CoV-2

The most frequently cited reasons why the 1148 parents intend to vaccinate their children (multiple choice question) are the children's protection against infection, the protection of a person at risk in the family, but also the desire to be able to travel without restrictions (Table No. 5). 
Table number 5 . The reasons why parents would vaccinate their children

\begin{tabular}{|c|c|}
\hline They want to protect them from infection & 1062 \\
\hline They want to protect a person at risk in the family & 268 \\
\hline They want to travel without restrictions & 436 \\
\hline \multirow{2}{*}{\multicolumn{2}{|c|}{$\begin{array}{l}\text { The main reasons why parents do not intend to fear of side effects and because they do not trust vac- } \\
\text { vaccinate their children are: the fact that they do not cines (Table 6). } \\
\text { consider it necessary to vaccinate their children, the } \\
\text { Table number } 6 \text {. Reasons why parents do not intend to vaccinate their children }\end{array}$}} \\
\hline & \\
\hline they do not consider it necessary to vaccinate children & 1175 \\
\hline fear of side effects & 1111 \\
\hline they do not trust vaccines & 514 \\
\hline they consider that there are not enough studies for their age group & 20 \\
\hline children's medical problems & 13 \\
\hline children already had COVID-19 & 6 \\
\hline
\end{tabular}

Perception of disease risk

$81.05 \%$ of parents consider that their children's risk of infection in the following period is between 0 and low (Table no. 7).

Table number 7. Probability of children getting infected with SARS-CoV-2 virus, as perceived by parents

\begin{tabular}{cc}
\hline zero & $\mathbf{5 4 9}(\mathbf{1 5 , 5 7 \%}$ \\
\hline very low & $\mathbf{9 8 1}(\mathbf{2 7 , 8 3 \% )}$ \\
\hline low & $\mathbf{1 3 2 7 ( 3 7 , 6 5 \% )}$ \\
\hline high & $\mathbf{5 5 8 ( 1 5 , 8 3 \% )}$ \\
\hline very high & $\mathbf{1 0 9 ( 3 , 0 9 \% )}$ \\
\hline
\end{tabular}

COVID-19 and chronic illnesses of children included in the study

Only $10 \%(353)$ of the children reported in this study had COVID-19, about 2.58\% (91) do not know if they were infected or not, while $87.4 \%$ (3080) of the children did not have COVID-19 - according to the answers given by parents.

Regarding the chronic diseases of children reported in this study, $2.07 \%$ suffer from chronic diseases, the highest prevalence being represented by asthma $(\mathrm{N}=43)$, followed by cardiovascular diseases $(\mathrm{N}=7)$, type I diabetes mellitus $(\mathrm{N}=6)$ and epilepsy and psychiatric illness $(\mathrm{N}=8) ; 3$ children have an allergic history.

Analysis of the correlations between different variables and the intention to vaccinate children 


\section{Parents' age}

Table number $\mathbf{8}$. Analysis of vaccination intention by parents' age

\begin{tabular}{|c|c|c|c|c|c|}
\hline & & & \multicolumn{2}{|c|}{ Intention to vaccinate children } & \multirow[t]{2}{*}{ Total } \\
\hline & & & yes & no & \\
\hline \multirow{10}{*}{ Parent age } & \multirow{2}{*}{$<30$} & $\mathrm{~N}$ & 6 & 29 & 35 \\
\hline & & $\%$ & $17.1 \%$ & $82.9 \%$ & $100.0 \%$ \\
\hline & \multirow{2}{*}{$30-35$} & $\mathrm{~N}$ & 105 & 379 & 484 \\
\hline & & $\%$ & $21.7 \%$ & $78.3 \%$ & $100.0 \%$ \\
\hline & \multirow{2}{*}{$35-40$} & $\mathrm{~N}$ & 234 & 695 & 929 \\
\hline & & $\%$ & $25.2 \%$ & $74.8 \%$ & $100.0 \%$ \\
\hline & \multirow{2}{*}{$40-45$} & $\mathrm{~N}$ & 497 & 880 & 1377 \\
\hline & & $\%$ & $36.1 \%$ & $63.9 \%$ & $100.0 \%$ \\
\hline & \multirow{2}{*}{$>45$} & $\mathrm{~N}$ & 306 & 393 & 699 \\
\hline & & $\%$ & $43.8 \%$ & $56.2 \%$ & $100.0 \%$ \\
\hline
\end{tabular}

$\chi^{2}=100.65, p<0.01, \varphi=0.17$

From Table 8 it can be seen that as the parents' age increases, the proportion of participants with the intention to vaccinate their children increases. This relationship is statistically significant $\left(\chi^{2}=100.65, p<0.01\right)$ and of low intensity $(\varphi=0.17)$.

\section{Parents' domicile}

Table 9. Analysis of the intention to vaccinate according to the domicile

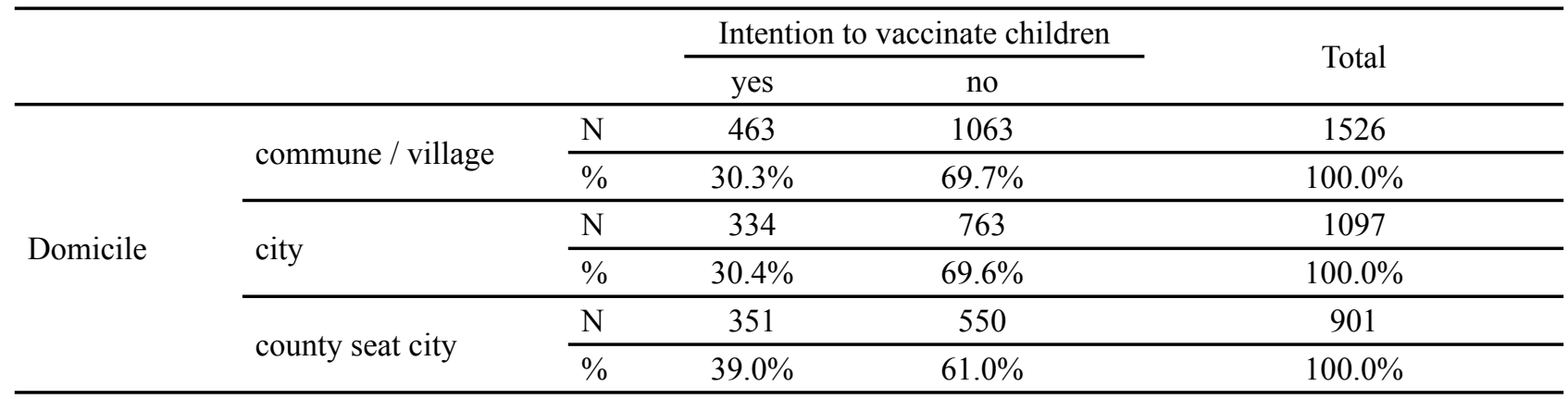

$\chi^{2}=22.43, p<0.01, \varphi=0.08$

In county seat cities the proportion of partici- from rural areas or from smaller cities. This relationpants with the intention of vaccinating their children is higher compared to the proportion of participants ship is statistically significant $\left(\chi^{2}=22.43, \mathrm{p}<0.01\right)$ and of low intensity $(\varphi=0.08)$ (Table no. 9). 


\section{Development region}

Table number 10. Analysis of vaccination intention by development region

\begin{tabular}{|c|c|c|c|c|c|}
\hline & & & \multicolumn{2}{|c|}{ Intention to vaccinate children } & \multirow{2}{*}{ Total } \\
\hline & & & yes & no & \\
\hline \multirow{16}{*}{ Region } & \multirow{2}{*}{ București/Ilfov } & $\mathrm{N}$ & 52 & 168 & 220 \\
\hline & & $\%$ & $23.6 \%$ & $76.4 \%$ & $100.0 \%$ \\
\hline & \multirow{2}{*}{ Center } & $\mathrm{N}$ & 205 & 331 & 536 \\
\hline & & $\%$ & $38.2 \%$ & $61.8 \%$ & $100.0 \%$ \\
\hline & \multirow{2}{*}{ North-East } & $\mathrm{N}$ & 9 & 16 & 25 \\
\hline & & $\%$ & $36.0 \%$ & $64.0 \%$ & $100.0 \%$ \\
\hline & \multirow{2}{*}{ North-West } & $\mathrm{N}$ & 64 & 136 & 200 \\
\hline & & $\%$ & $32.0 \%$ & $68.0 \%$ & $100.0 \%$ \\
\hline & \multirow{2}{*}{ South-Muntenia } & $\mathrm{N}$ & 709 & 1453 & 2162 \\
\hline & & $\%$ & $32.8 \%$ & $67.2 \%$ & $100.0 \%$ \\
\hline & \multirow{2}{*}{ South-East } & $\mathrm{N}$ & 14 & 12 & 26 \\
\hline & & $\%$ & $53.8 \%$ & $46.2 \%$ & $100.0 \%$ \\
\hline & \multirow{2}{*}{ South-West Oltenia } & $\mathrm{N}$ & 54 & 158 & 212 \\
\hline & & $\%$ & $25.5 \%$ & $74.5 \%$ & $100.0 \%$ \\
\hline & \multirow{2}{*}{ West } & $\mathrm{N}$ & 41 & 102 & 143 \\
\hline & & $\%$ & $28.7 \%$ & $71.3 \%$ & $100.0 \%$ \\
\hline
\end{tabular}

$\chi^{2}=27.28, p<0.01, \varphi=0.09$

The highest proportion of participants with the intention to vaccinate their children is in the SouthEast Region (53.8\%), followed by the Center Region (38.2\%) and the North-East Region (36.0\%). The regions with the lowest percentages favorable to

\section{Level of education}

Table number 11. Analysis of vaccination intention by parents' level of education

\begin{tabular}{|c|c|c|c|c|c|}
\hline & & & \multicolumn{2}{|c|}{ Intention to vaccinate children } & \multirow{2}{*}{ Total } \\
\hline & & & yes & no & \\
\hline \multirow[t]{10}{*}{ Education } & \multirow[t]{2}{*}{ no education } & $\mathrm{N}$ & 1 & 6 & 7 \\
\hline & & $\%$ & $14.3 \%$ & $85.7 \%$ & $100.0 \%$ \\
\hline & \multirow[t]{2}{*}{ gymnasium } & $\mathrm{N}$ & 91 & 306 & 397 \\
\hline & & $\%$ & $22.9 \%$ & $77.1 \%$ & $100.0 \%$ \\
\hline & \multirow[t]{2}{*}{ high school } & $\mathrm{N}$ & 309 & 853 & 1162 \\
\hline & & $\%$ & $26.6 \%$ & $73.4 \%$ & $100.0 \%$ \\
\hline & \multirow[t]{2}{*}{ post secondary school } & $\mathrm{N}$ & 167 & 337 & 504 \\
\hline & & $\%$ & $33.1 \%$ & $66.9 \%$ & $100.0 \%$ \\
\hline & \multirow[t]{2}{*}{ higher education } & $\mathrm{N}$ & 580 & 874 & 1454 \\
\hline & & $\%$ & $39.9 \%$ & $60.1 \%$ & $100.0 \%$ \\
\hline
\end{tabular}

$\chi^{2}=72.34, p<0.01, \varphi=0.14$ vaccination are Bucharest / Ilfov (23.6\%), followed by the South-West Oltenia Region $(25.5 \%)$ and the West Region (28.7\%). These differences are statistically significant $\left(\chi^{2}=27.28, \mathrm{p}<0.01\right)$ and of low intensity $(\varphi=0.09)$ (Table no. 10$)$. 
As the level of education increases, the proportion of participants with the intention of vaccinating their children increases. This relationship is statistically significant $\left(\chi^{2}=72.34, p<0.01\right)$ and of low intensity $(\varphi=0.14)$ (Table no. 11).

\section{Vaccination status}

Table 12. Analysis of the intention to vaccinate according to the SARS-CoV2 vaccination status of the respondent parent

\begin{tabular}{lllccc}
\hline & & & \multicolumn{2}{c}{ Intention to vaccinate children } & \multirow{2}{*}{ Total } \\
\cline { 3 - 6 } & & & yes & no & 1652 \\
\hline \multirow{3}{*}{ Vaccinated parent } & \multirow{2}{*}{ yes } & $\mathrm{N}$ & 873 & 779 & $100.0 \%$ \\
\cline { 2 - 6 } & & $\%$ & $52.8 \%$ & $47.2 \%$ & 1872 \\
\cline { 2 - 5 } & \multirow{2}{*}{ no } & $\mathrm{N}$ & 275 & 1597 & $100.0 \%$ \\
\cline { 2 - 5 } & & $\%$ & $14.7 \%$ & $85.3 \%$ & \\
\hline
\end{tabular}

$\chi^{2}=581.65, p<0.01, \varphi=0.40$

In the group of vaccinated parents, the proportion of those with the intention to vaccinate their children is approximately 3.5 times higher $(52.8 \%)$ than in the group of unvaccinated parents (14.7\%). This difference is statistically significant $\left(\chi^{2}=581.65, \mathrm{p}\right.$ $<0.01)$ and of medium to high intensity $(\varphi=0.40)$ (Table no. 12).

\section{Risk factors in the family}

Table 13. Analysis of vaccination intention according to the existence of risk factors in the family

\begin{tabular}{lllcccc}
\hline & & & \multicolumn{2}{c}{ Intention to vaccinate children } & \multirow{2}{*}{ Total } \\
\cline { 3 - 6 } & & & \multicolumn{2}{c}{ yes } & no \\
\hline \multirow{2}{*}{ Risk factors in the family } & \multirow{2}{*}{ yes } & $\mathrm{N}$ & 536 & 780 & 1316 \\
\cline { 3 - 6 } & & $\%$ & $40.7 \%$ & $59.3 \%$ & $100.0 \%$ \\
\cline { 2 - 6 } & \multirow{2}{*}{ no } & $\mathrm{N}$ & 612 & 1596 & 2208 \\
\cline { 2 - 6 } & & $\%$ & $27.7 \%$ & $72.3 \%$ & $100.0 \%$ \\
\hline
\end{tabular}

$\chi^{2}=63.56, p<0.01, \varphi=0.13$

In the group of respondents who have family members with risk factors, the proportion of those with the intention to vaccinate their children is about 1.4 times higher $(40.7 \%)$ than in the group of

The existence of COVID-19 in the family

Table 14. Analysis of vaccination intention in regard to the existence of COVID-19 cases in the family

\begin{tabular}{lllccr}
\hline & & & \multicolumn{2}{c}{ Intention to vaccinate children } & \multicolumn{2}{c}{ Total } \\
\cline { 3 - 5 } & & & yes & no & 1188 \\
\hline \multirow{2}{*}{ COVID-19 in the family } & \multirow{2}{*}{ yes } & $\mathrm{N}$ & 409 & 779 & $100.0 \%$ \\
\cline { 2 - 5 } & & $\%$ & $34.4 \%$ & $65.6 \%$ & 2336 \\
\cline { 2 - 5 } & \multirow{2}{*}{ no } & $\mathrm{N}$ & 739 & 1597 & $100.0 \%$ \\
\cline { 2 - 5 } & & $\%$ & $31.6 \%$ & $68.4 \%$ & 0 \\
\hline
\end{tabular}

$\chi^{2}=2.79, p=0.095, \varphi=0.02$

$34.4 \%$ of participants with COVID-19 cases in the family and $31.6 \%$ of those without such cases express their intention to vaccinate their children, a respondents without family members with risk factors $(27.7 \%)$. This difference is statistically significant $\left(\chi^{2}=63.56, p<0.01\right)$ and of low intensity $(\varphi=0.13)$ (Table no. 13). 


\section{The existence of severe COVID-19 cases in the family}

Table 15. Analysis of vaccination intention in regard to the existence of severe cases of COVID-19 in the family

\begin{tabular}{|c|c|c|c|c|c|}
\hline & & & \multicolumn{2}{|c|}{$\begin{array}{l}\text { Intention to vaccinate } \\
\text { children }\end{array}$} & \multirow[t]{2}{*}{ Total } \\
\hline & & & yes & no & \\
\hline \multirow[t]{8}{*}{ COVID-19 cases } & \multirow[t]{2}{*}{ family member died } & $\mathrm{N}$ & 34 & 46 & 80 \\
\hline & & $\%$ & $42.5 \%$ & $57.5 \%$ & $100.0 \%$ \\
\hline & \multirow[t]{2}{*}{ family member was in the ICU } & $\mathrm{N}$ & 13 & 8 & 21 \\
\hline & & $\%$ & $61.9 \%$ & $38.1 \%$ & $100.0 \%$ \\
\hline & \multirow[t]{2}{*}{ family member was hospitalized } & $\mathrm{N}$ & 77 & 128 & 205 \\
\hline & & $\%$ & $37.6 \%$ & $62.4 \%$ & $100.0 \%$ \\
\hline & \multirow[t]{2}{*}{ no severe case in the family } & $\mathrm{N}$ & 1024 & 2194 & 3218 \\
\hline & & $\%$ & $31.8 \%$ & $68.2 \%$ & $100.0 \%$ \\
\hline
\end{tabular}

$\chi^{2}=14.96, p<0.01, \varphi=0.06$

Participants who had COVID-19 cases in the family that required ICU intervention or that ended in death reported higher percentage $(61.9 \%$ and $42.5 \%$, respectively) of children vaccination intentions, compared to respondents whose family members needed hospitalization or where there were no severe cases in the family (37.6\% and $31.8 \%$, respectively). These differences are statistically significant $\left(\chi^{2}=14.96, p\right.$ $<0.01)$ and of low intensity $(\varphi=0.06)$ (Table no.15).

\section{DISCUSIONS}

The present study explored, through a webbased questionnaire, the factors that may influence the decision of Romanian parents regarding the anti SARS-CoV-2 vaccination of children aged between 12 and 15 years.

The questionnaires received from 3524 parents, with an average age of 40.36 years, from all geographical regions of Romania, were studied. The intention to vaccinate their children aged $12-15$ was $32.57 \%$. We find that the intention to vaccinate children is comparable to that in Turkey (33\%) [15], but lower than that reported in studies conducted in other countries: $48.2 \%$ in England [22], $49.4 \%$ in the US [23] and $72.6 \%$ in China [20]. There are also differences between the percentage of parents who received the COVID-19 vaccine (46.87\%) and the intention to vaccinate their own children $(32.57 \%)$.
The reasons why parents intend to vaccinate their children are represented in $92.5 \%$ of cases by the desire to protect their children against infection; in addition, the protection of a family member with risk factors is considered a good reason to vaccinate their children by $23.34 \%$ of parents, and $38 \%$ want to vaccinate their children out of the desire to be able to travel without restrictions.

The reasons why parents do not want to vaccinate their children against COVID-19 are: the fact that they do not consider it necessary to vaccinate children $(49.45 \%)$, the fear of side effects $(46.75 \%)$ and because they do not trust vaccines $(21,63 \%)$. It is observed that the percentage of parents who do not vaccinate their children against COVID-19 because they do not trust the vaccines is consistent with their non-acceptance of vaccines from the national immunization programme.

A study carried out in Turkey [21], similar to ours, reports as main reasons for refusing the vaccine: the fear of side effects, insufficient knowledge of the vaccine's effectiveness and distrust of vaccines produced abroad. One of the studies on this topic conducted in the USA [23] reports as important reasons in the hesitation / refusal of vaccination the safety, efficacy and the fact that the vaccine would not be necessary (according to the respondents).

Regarding the intention to vaccinate, it correlates significantly with the older age of the parents, the high level of education, and the domicile in county seat cities. 
An important statistical correlation was found between the vaccinated status of parents and the intention to vaccinate their children, as well as between this intention and the presence of family members at high risk of developing a severe form of the disease. There is no statistically significant relationship between the intention to vaccinate and the fact that there were cases of COVID-19 in the family, instead there is a statistically significant association when the form of the disease in the family was severe.

The low level of education of parents and the low level of their income were significantly correlated with hesitation / refusal of vaccination in studies conducted in other countries $[23,24]$.

\section{CONCLUSIONS}

The results of this study reveal a relatively low intention to vaccinate children against the SARSCoV-2 virus compared to other countries in the world, only less than 1 in 3 surveyed parents reporting that they intend to vaccinate their child/children aged 1215 against the SARS-CoV-2 virus when a vaccine becomes available. The reasons given for the refusal of vaccination and the correlations we highlighted outline the profile of the parent who refuses vaccination, who has the following characteristics:

- Rather with low income levels

- Rather with low levels of education

- Unvaccinated against SARS-CoV-2

- Rather from a rural environment or from smaller cities

- With a low level of information and awareness on: 1) the risk of disease and its negative impact on children's health and 2) the effectiveness of the SARS-CoV-2 vaccine and vaccines in general in preventing the contact of infectious diseases with possible severe side effects among children.

The identification of this parent profile, corroborated with results from other studies (possibly qualitative, using focus-group methods) to clarify / certify certain characteristics identified in this quantitative exploratory study, can help identify target groups for campaigns on information, education and awareness of the importance of vaccinating children (and the general population, given the correlation between the vaccination status of the parent and the intention to vaccinate the child) against the SARS-CoV-2 virus. Knowing the characteristics of the target group allows the development of materials and means of dissemination appropriate to the understanding, knowledge and values of this group, maximizing the impact of these campaigns.

\section{IMPLICATIONS}

The implications of the results of this study in professional, in the medical system, and decision-making plan, refer to the channeling of limited available resources to those activities that can improve the vaccination rate, respectively the use of primary medicine in the process of informing and raising public awareness, given the fact that the medical staff still enjoys a high degree of trust from the population and is a model for it. 


\section{REFERENCES}

1.Zimet DG, Silverman DR, Fortenberry JD. Coronavirus Disease 2019 and Vaccination of Children and Adolescents: Prospects and Challenges. J Pediatr. 2021;231:254258. doi: $10.1016 /$ j.jpeds.2020.11.002

2. Viner RM, Mytton OT, Bonell C, Melendez-Torres GJ, Ward J, Hudson L. Susceptibility to SARS-CoV-2 infection among children and adolescents compared with adults: a systematic review and meta-analysis. JAMA Pediatr. 2020 [Epub ahead of print] [PMC free article] [PubMed] [Google Scholar]

3. Park YJ, Choe YJ, Park O, Park SY, Kim YM, Kim J. Contact tracing during coronavirus disease outbreak, South Korea, 2020. Emerg Infect Dis. 2020;26:2465-2468. [PMC free article] [PubMed] [Google Scholar]

4. Szablewski CM, Chang KT, Brown MM, Chu VT, Yousaf AR, Anyalechi N. SARS-CoV-2 transmission and infection among attendees of an overnight camp - Georgia, June 2020. MMWR Morb Mortal Wkly Rep. 2020;69:1023-1025. [PMC free article] [PubMed] [Google Scholar]

5. Lopez AS, Hill M, Antezano J, Vilven D, Rutner T, Bogdanow L. Transmission dynamics of COVID-19 outbreaks associated with child care facilities - Salt Lake City, Utah, April-July 2020. MMWR Morb Mortal Wkly Rep. 2020;69:13191323. [PMC free article] [PubMed] [Google Scholar]

6. Schwartz NG, Moorman AC, Makaretz A, Chang KT, Chu VT, Szablewski CM. Adolescent with COVID-19 as the source of an outbreak at a 3-week family gathering-four states, June-July 2020. MMWR Morb Mortal Wkly Rep. 2020;69:14571459. [PMC free article] [PubMed] [Google Scholar]

7. Anderson E, Campbell J, Creech C, Frenck R, Kamidani S, Munoz F, Nachman S, Spearman P. Warp speed for COVID-19 vaccines: Why are children stuck in neutral? Clin Infect Dis. 2020 Sep 18;:1. doi: 10.1093/cid/ciaa1425. http://europepmc.org/abstract/MED/32945335. [PMC free article] [PubMed] [CrossRef] [Google Scholar]

8. Kest H, Kaushik A, DeBruin W, Colletti M, Goldberg D. Multisystem Inflammatory Syndrome in

Children (MIS-C) Associated with 2019 Novel Coronavirus (SARS-CoV-2) Infection. Case Rep

Pediatr. 2020;2020:8875987.

9. Cainap S, Mititelu A, Pantar O, Lazar D. Multisystem Infl ammatory Syndrome associated SARS-CoV-2. A novel spectrum of pediatric ilness. The Journal of School and University Medicine 2021;VIII(1):36-40

10. Jiang LI, Tang K, Levin M, et al. COVID- 19 and multisystem inflam-matory syndrome in children and adolescents. Lancet Infect Dis. 2020;20:e276- e288.

11. Buonsenso D, Munblit D, De Rose C, et al. Preliminary evidence on long COVID in children. Acta paediatrica. 2021

12. Amercian Academy of Pediatrics (AAP) and Children's Hospital Association. Children and COVID-19: State
Data Report Version: May 13, 2021. https://services.aap. org/en/pages/2019-novelcoronavirus-covid-19-infections/ children-and-covid-19-state-level-data-report/.

13.https://www.cdc.gov/mmwr/volumes/70/wr/ $\mathrm{mm} 7023 \mathrm{e} 1 . \mathrm{htm}$ ?s_cid $=\mathrm{mm} 7023 \mathrm{e} 1$ e\&ACSTrackingID $=$ US CDC_921-DM58809\&ACSTrackingLabel=MMWR\%20 Early\%20Release\%20-\%20Vol.\%2070\%2C\%20June\%20 4\%2C\%202021\&deliveryName=USCDC_921-DM58809\&fbclid=IwAR0YSN2 AmOkhao 7zRwfG5O7k0p11p9u 5 C3sPNBnB2_Vw5jmCouU31QMtoiY

14.Klass P, Ratner AJ. Vaccinating children against covid19 - the les-sons of measles. N Engl J Med. 2021;384:589- 591.

15. Yilmaz M, Sahin MK. Parents' willingness and attitudes concerning the COVID- 19 vaccine: A cross- sectional study. Int J Clin Pract. 2021;00:e14364.

16.Fadda M, Albanese E, Suggs LS. When a COVID-19 vaccine is ready, will we all be ready for it? Int J Public Health. 2020;65(6):711-712. - PMC - PubMed

17.Dubé E, Laberge C, Guay M, Bramadat P, Roy R, Bettinger JA. Vaccine hesitancy: An overview. Human Vaccines \& Immunotherapeutics. 2013;9(8):1763-1773. - PMC - PubMed

18. Goldman RD, Staubli G, Cotanda CP, et al. Factors associated with parents' willingness to enroll their children in trials for COVID- 19 vaccination. Hum Vaccines Immunother. 2020; 17 1607- 1611.

19. Goldman RD, Yan TD, Seiler M, et al. Caregiver willingness to vac-cinate their children against COVID- 19: Cross sectional survey. Vaccine. 2020;38 7668-7673.

20. Zhang KC, Fang Y, Cao HE, et al. Parental acceptability of COVID- 19 vaccination for children under the age of 18 years: cross - sectional online survey. JMIR Pediatr Parent. 2020;3:e24827.

21. Yigit M, Ozkaya-Parlakay A, Senel E. Evaluation of COVID-19 Vaccine Refusal in Parents. Pediatr Infect Dis J. 2021 Apr 1;40(4):e134-e136. doi: 10.1097/INF.0000000000003042. PMID: 33410650.

22. Bell S, Clarke R, Mounier-Jack S, Walker JL, Paterson P. Parents' and guardians' views on the acceptability of a future COVID-19 vaccine: A multi-methods study in England. Vaccine. 2020 Nov 17;38(49):7789-7798. doi: 10.1016/j.vaccine.2020.10.027. Epub 2020 Oct 19. PMID: 33109389; PMCID: PMC7569401.

23.Teasdale AC, Borrell NL, Shen Y, Kimball S, Rinke LM, Fleary AS, Nash D. Parental plans to vaccinate children for COVID-19 in New York City.

24. Rhodes ME, Sundstrom B, Ritter E, McKeever BW, McKeever R. Preparing for A COVID-19 Vaccine: A Mixed Methods Study of Vaccine Hesitant Parents. J Health Commun. 2020 Oct 2;25(10):831-837. doi: 10.1080/10810730.2021.1871986. PMID: 33719886. 